\title{
Immunoglobulin containing cells in terminal ileum and colorectum of patients with arthritis related gut inflammation
}

\author{
C CUVELIER, H MIELANTS, M DE VOS, E VEYS, AND H ROELS \\ From the Department of Pathology, Rheumatology, and Gastroenterology, State University of Ghent, Belgium
}

SUMmaRy In 40 distal ileal and 40 colonic biopsies of arthritic patients mostly without gastrointestinal symptoms, but with histological evidence of acute or chronic inflammation of the gut, the number of immunoglobulin (Ig) containing plasma cells was studied morphometrically using a peroxidase antiperoxidase technique. Compared with controls, the ileal mucosal biopsies showed an increase of IgA and IgG in acute ileitis. In chronic ileitis there was an increase of IgA, IgG, and IgM similar to Crohn's disease. In colonic biopsies there was a significant increase of all immunoglobulin classes in acute inflammation. In chronic inflamed mucosa there was also an increase of all three Ig classes. The Ig distribution, however, was significantly different in acute and chronic colitis. These findings give immunohistochemical evidence of the existence of two different types of inflammation related to reactive arthritis or the peripheral joint involvement of ankylosing spondylitis. The Ig pattern in acute colitis is similar to that found in infectious colitis, suggesting an enterobacterial origin of the arthritis in this group of patients although bacteriological and serological investigations were negative. In the chronic type of arthritis related ileocolitis, the pattern of Ig containing cells is similar to that found in Crohn's disease but different from infectious and ulcerative colitis, which makes the hypothesis that a great number of these arthritis patients suffer from asymptomatic or subclinical Crohn's disease acceptable.

Patients with reactive arthritis and peripheral joint involvement of ankylosing spondylitis have frequently asymptomatic acute or chronic gut inflammation often indistinguishable from Crohn's disease, and localised in terminal ileum and/or colorectum. ${ }^{12}$ In acute and chronic diseases the inflammation is characterised by an increased number of mucosal lymphocytes, plasma cells, neutrophils, and eosinophils. The inflammatory cell infiltration of the ileocolonic mucosa is the expression of an immunological reaction, which has already been studied in acute infectious colitis ${ }^{34}$ and in chronic idiopathic inflammatory bowel disease (IBD) with an immuno-

Address for correspondence: Dr C Cuvelier, N Goormaghtigh Institute of Pathology, University Hospital, De Pintelaan 185, B-900) Ghent. Belgium. Received for publication 22 January 1988 fluorescence technique ${ }^{5-7}$ and with the immunoperoxidase technique. ${ }^{-11}$ The advantages of an immunoperoxidase technique on paraplast embedded sections are that the type of labelled cells is easy to identify, that other inflammatory cells can be distinguished, that the sections are more appropriate for morphometry and that sections can be kept indefinitely.

In acute infectious colitis immunoglobulin (Ig) A and $\operatorname{IgM}^{+}$or $\operatorname{IgA}$ and $\operatorname{IgE}^{\prime \prime}$ containing plasma cells were found to be increased. In chronic idiopathic IBD most authors found an increase of all three major classes of Ig containing cells ${ }^{5111}$ or of $\mathrm{IgG}^{\mathrm{x}}$ containing cells in ulcerative colitis, an increase of IgG and IgM containing cells in active Crohn's disease and a relative increase of IgM containing cells in quiescent Crohn's disease. ${ }^{1012}$

In macroscopically normal rectal mucosa of 
patients with ankylosing spondylitis, Stodell et $\mathrm{al}^{13}$ found a significant increase of IgG containing cells but no significant increase of the total number of lamina propria plasma cells.

In the present study we examined morphometrically the numbers of $\operatorname{IgA}, \operatorname{IgG}, \operatorname{IgM}$, and $\operatorname{IgE}$ containing plasma cells in terminal ileal and colonic biopsies of patients with reactive arthritis and ankylosing spondylitis with a peroxidase antiperoxidase technique. These were compared with Ig containing cells of patients with infectious colitis, ulcerative colitis, Crohn's disease, and of healthy controls. The purpose was to determine the pattern of Ig containing plasma cells in gut inflammation related to arthritis in order to discriminate acute and chronic inflammation and to distinguish arthritis related gut inflammation from acute bacterial enterocolitis and from chronic idiopathic IBD.

\section{Methods}

\section{PATIENTS}

In the terminal ileum three groups of patients were studied.

\section{CONTROLS}

Ileal biopsies of 10 patients without evidence of IBD who had ileocolonoscopy because of polyps, adenocarcinoma of the colon or chronic constipation, were examined. The patients consisted of four women and six men with a mean age of $54 \cdot 6$ years $(42-65)$.

\section{ARTHRITIS RELATED GUT INFLAMMATION}

This group consisted of 40 patients suffering from seronegative spondyloarthropathies, 15 women and 25 men with a mean age of 36 years (16-69). Seronegative spondylarthropathy is accepted as a specific disease entity with specific features: $:^{14}$ absence of rheumatoid factors and nodules, peripheral inflammatory arthritis, sacroileitis with or without spondylitis, presence of entesopathies, clinical overlap of different diseases classified into the concept, familial aggregation and a significant association with HLA-B27. From these patients there were only seven who had previous gastrointestinal symptoms, mainly short periods of recurrent diarrhoea. Nine patients had ileocolitis and 31 had only ileitis on histological examination. The type of inflammation was subdivided into acute and chronic as previously described. In summary: acute inflammation is characterised by preserved crypt architecture, epithelial infiltration with polymorphonuclear leucocytes (cryptitis) and crypt abscesses. In contrast, the main features of chronic inflammation are crypt distortion and atrophy, increased mixed lamina propria cellularity, villous surface of colonic mucosa, villous blunting and fusion and basal lymphoid aggregates in the propria (Fig. 1a, b). The same histological criteria were used in ileal and colonic biopsies.

In 20 patients there was an acute pattern of inflammation, characterised by a polymorphonuclear cell infiltrate in the surface and crypt epithelium, formation of crypt abscesses and increase of mononuclear cell infiltrates in the lamina propria without epithelial alterations.

Twenty patients featured a chronic type of ileitis or ileitis similar to Crohn's disease, with microgranulomas and increased mononuclear cell content in the lamina propria, villous fusion and blunting and crypt distortion.

Thirty four of these patients were treated with nonsteroidal anti-inflammatory drugs (NSAIDs). The remainder were not treated.

CROHN'S DISEASE

This group consisted of 20 patients with terminal ileitis, 11 women and nine men, mean age $29 \cdot 6$ years (13-54). All patients had active Crohn's disease and the diagnosis was made on history, radiological, and endoscopic findings combined with histopathological findings as described by Morson, ${ }^{15}$ Rotterdam and Sommers, ${ }^{16}$ and Whitehead. ${ }^{17}$ Fourteen patients were treated with oral sulphasalazine, two used low doses of corticosteroids, and four had no treatment after surgical intervention. The severity of the disease was not taken into account and active as well as quiescent disease stages were examined.

In the colorectum five groups of patients were studied.

CONTROLS

Colonic biopsies of 10 patients without colitis were studied, four women and six men, mean age 54.6 years (42-65). The patients had colonoscopy because of polyps, adenocarcinoma, or chronic constipation.

\section{ARTHRITIS RELATED GUT INFLAMMATION}

In this group 40 patients were studied, 12 women and 28 men, mean age of 36 years (4-69). Six patients of this group had previous episodes of diarrhoea, whereas the others had no gastrointestinal symptoms. Acute inflammation was histologically present in 20 patients. Thereof, 18 had acute colitis as well as acute ileitis and two had acute colitis only. The other 20 patients had histological features of chronic colitis which was in all cases accompanied by chronic ileitis. Patients with ankylosing spondylitis featured mainly chronic ileocolitis $(80 \%)$. $^{\text {1* }}$

From these patients 34 were treated with NSAID's, whereas the others received no medical treatment. 


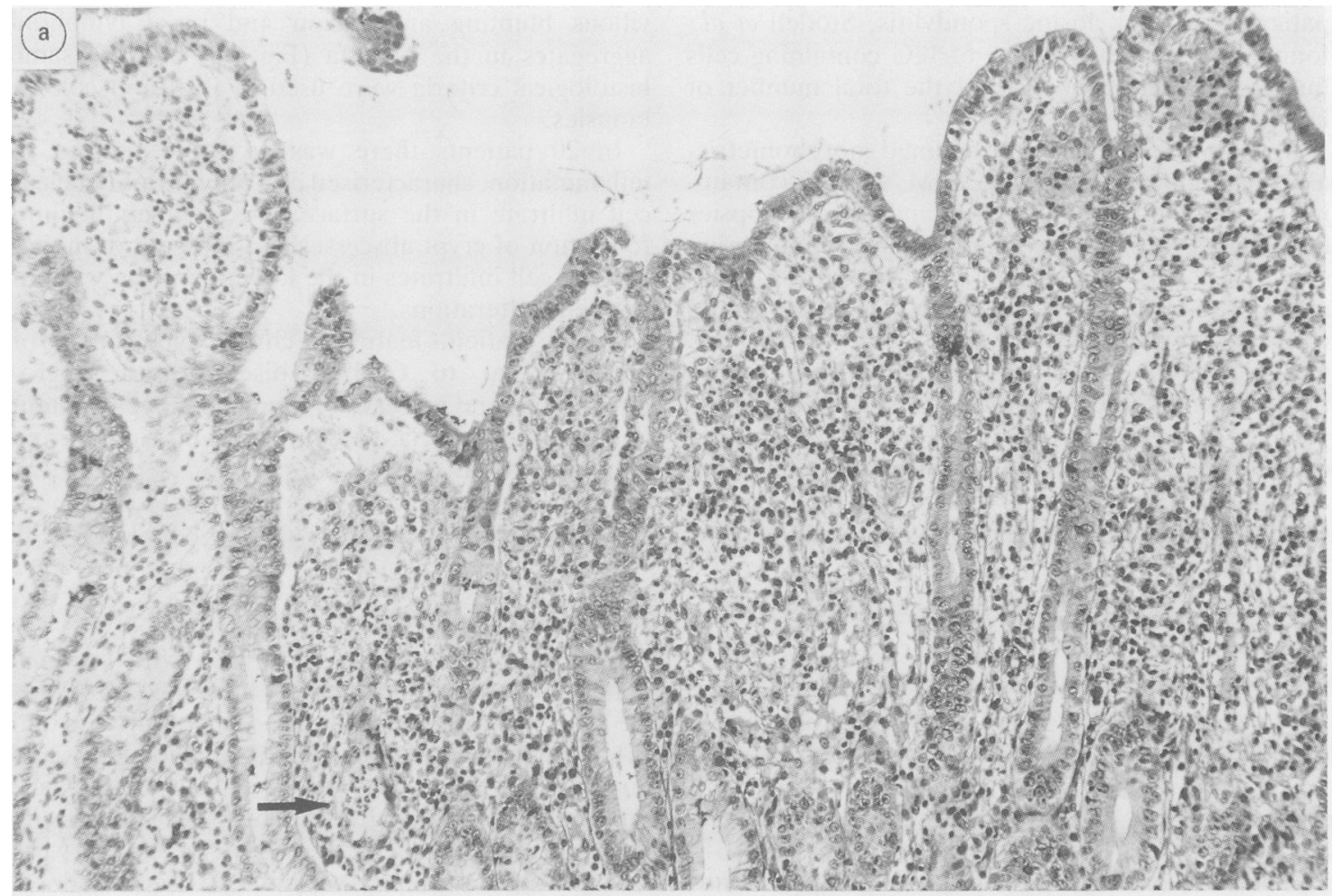

(b)
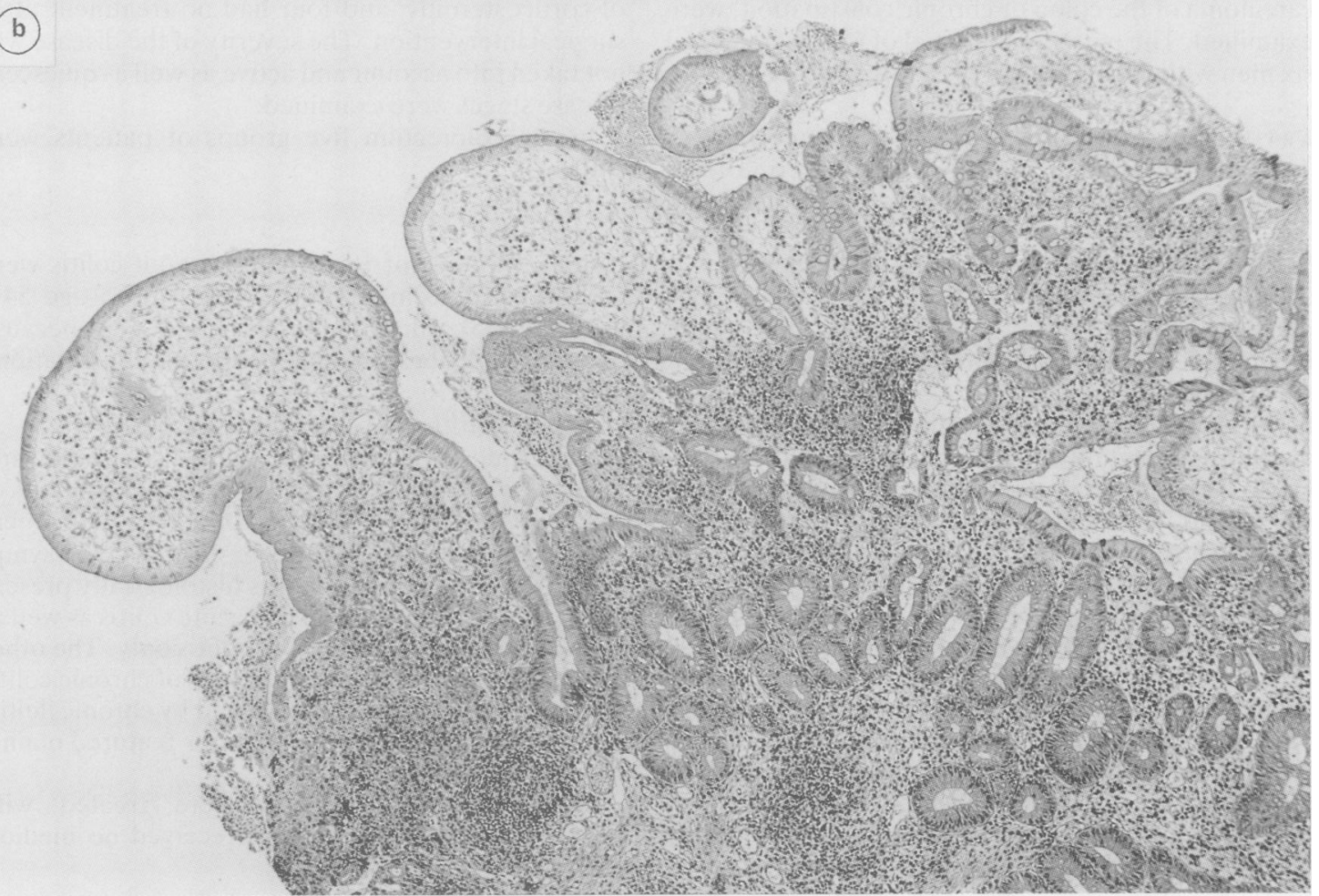


\section{INFECTIOUS COLITIS}

Biopsies of 10 patients (five women, five men) with an average age of 39.4 years $(21-57)$ with proven Salmonella colitis, Shigella colitis, or Campylobacter colitis were studied. All biopsies showed features of active inflammation - that is, cryptitis.

\section{ULCERATIVE COLITIS}

Biopsies of 20 patients with ulcerative colitis were examined. The patients were seven women and 13 men with an average age of 36.5 years (17-60). The diagnosis was established on clinical, radiological, endoscopical, and histological findings. All patients had active colorectal disease and 18 of them were treated with oral sulphasalazine, combined with low dose corticosteroids in five patients. Two patients had no medical treatment.

\section{CROHN'S DISEASE}

There were 20 biopsies studied of patients with colonic Crohn's disease: 11 women and nine men with a mean age of 32.9 years (13-64). For the diagnosis of Crohn's disease, the same diagnostic criteria as in the terminal ileum were used. No account was taken of the severity of the disease. Fifteen of the patients were treated with oral sulphasalazine, two used corticosteroids, and three were without medical treatment.

\section{PROCEDURES}

All patients, except those with infectious colitis, had an ileocolonoscopy. Patients gave verbal informed consent to the ileocolonoscopy and approval of the medical ethical committee was obtained. Biopsies were taken from the terminal ileum, ileocaecal valve, and colorectum at sites of abnormalities or blindly when there were no mascroscopic lesions. In order to obtain material most appropriate for immunohistochemical examination, the biopsies were immediately fixed in sublimate formaldehyde for three to four hours at room temperature and were then routinely processed and paraplast embedded. ${ }^{19}$ Sections were cut at $5 \mu$ and stained with haematoxylin and eosin. The biopsies were read blindly with a mixture of other gastrointestinal pathology by one of the authors (CC). After diagnosis was made, a selection of slides per case was cut at $5 \mu$ and specifically stained for $\operatorname{IgA}, \operatorname{IgE}, \operatorname{IgG}$, and $\operatorname{IgM}$ heavy chains, using the peroxidase antiperoxidase technique. Controls were done according to
Sternberger. ${ }^{20}$ The rabbit antisera against IgA, IgE, IgG, and IgM heavy chains were purchased from Dakopatts (Denmark). The monospecificity was confirmed by immunoelectrophoresis, immunofluorescence and immunoperoxidase staining of bone marrow preparations monoclonal for $\operatorname{IgA}, \operatorname{IgG}$, and IgM. The anti IgE-antiserum showed no reaction with bone marrow preparations monoclonal for $\operatorname{IgA}$, IgG, and IgM heavy chains and their $\mathrm{K}$ and $\lambda$ light chains. Horseradish peroxidase and rabbit antihorseradish peroxidase were also purchased from Dakopatts. The IgA, IgE, IgG, and IgM stained sections were morphometrically analysed using a turret eyepiece with integrating disk turret (Carl Zeiss) put on a standard routine microscope.

In every immunoperoxidase stained section the number of immunoglobulin containing cells was counted. It was determined in three consecutive sections per case, approximately in the same area and in $1 \mathrm{~mm}$ mucosa length using the same criteria as Rosekrans et al." A correction for shrinkage of the biopsy was applied: the lamina propria area was defined by two lines perpendicular to the muscularis mucosae. The so obtained area is comparable with the 'mucosal tissue unit' used by Brandtzaeg et al. ${ }^{21}$

Statistical analysis was done according to Student's two sample $t$ test. The rejection limit of the 0 hypothesis was fixed at $\mathrm{p}<0 \cdot 05$.

\section{Results}

In all studied groups the number of $\operatorname{IgE}$ containing cells was too low to allow reliable statistical analysis and therefore the data on IgE containing cells are not further taken into account.

The data are summarised in Table 1. Figures 2 and 3 illustrate the amount of $\operatorname{IgA}, \operatorname{IgG}$, and $\operatorname{IgM}$ containing cells in terminal ileum and colon per mm mucosa length. In order to compare the density of the inflammatory infiltrate, the distribution of Ig containing cells was expressed in percentage of cells. These data are presented in Table 2 .

\section{TERM INA L I LEUM}

In the group of controls the IgA containing cells predominated, whereas the number of IgG and IgM containing cells was less numerous (Fig. 4a).

In the acute type of arthritis related gut inflammation, the IgA containing cells were the major cell class, significantly increased when compared with the

Fig. 1 (a) Acute ileitis: there is villous blunting and thickening, epithelial infiltration by polymorphonuclear leucocytes and an increased amount of lymphocytes, plasmocytes and neutrophils in the lamina propria. A crypt abscess is present (arrow). $H$ and E. (b) Chronic ileitis: the mucosal surface is irregular with blunted villi. Crypts are irregular and the lamina propria contains an increased number of lymphocytes, plasma cells and neutrophils. There are basal lymphoid aggregates in the lamina propria. Hand $E$. 
Table 1 Number of $\operatorname{Ig} A, \lg G$, and $\lg M$ containing cells per millimetre mucosa length in terminal ileal and colonic biopsies

\begin{tabular}{llrrl}
\hline Group & Number & \multicolumn{1}{l}{$\operatorname{Ig} A$} & \multicolumn{1}{l}{$\lg G$} & \multicolumn{1}{l}{$\lg M$} \\
\hline Terminal ileum & & & & \\
Controls & 10 & $91(20)$ & $42(20)$ & $21(8)$ \\
Crohn's disease & 20 & $228(90)$ & $148(60)$ & $70(27)$ \\
Acute inflammation & 20 & $167(73)$ & $69(34)$ & $25(10)$ \\
Chronic inflammation & 20 & $213(74)$ & $152(75)$ & $90(36)$ \\
Colon & & & & \\
Controls & 10 & $99(17)$ & $43(15)$ & $14(3)$ \\
Infectious colitis & 10 & $223(52)$ & $51(14)$ & $25(7)$ \\
Ulccrative colitis & 20 & $287(64)$ & $227(79)$ & $75(27)$ \\
Crohn colitis & 20 & $184(60)$ & $121(36)$ & $69(26)$ \\
Acute inflammation & 20 & $193(30)$ & $65(17)$ & $26(10)$ \\
Chronic inflammation & 20 & $217(37)$ & $105(22)$ & $87(27)$ \\
\hline
\end{tabular}

Values are expressed as mean (SD).

controls $(p<0 \cdot 005)$ (Fig. 4b). There was a significant increase of IgG as well $(p<0 \cdot 05)$. The number of IgG containing cells, however, was significantly different from the IgG containing cells in the chronic type of gut inflammation and Crohn's disease $(p<0 \cdot 001)$. The IgM containing cells were not significantly increased. Here too the difference with the chronic type of arthritis related gut inflammation and Crohn's disease was highly significant $(\mathrm{p}<0 \cdot 001)$.
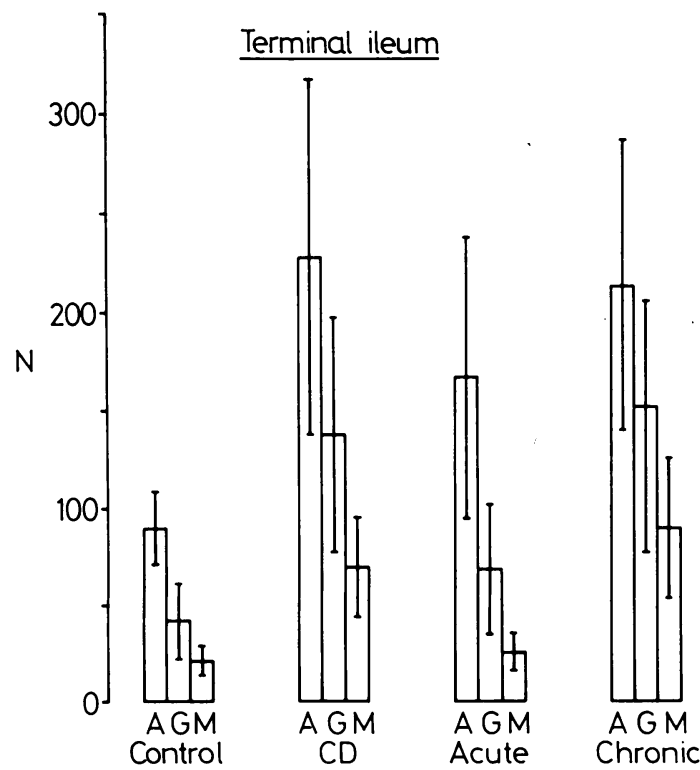

Fig. 2 Number of immunoglobulin containing cells per millimetre terminal ileal mucosa $(S D)$ in 10 controls, 20 patients with Crohn's disease, 20 patients with acute and 20 patients with chronic arthritis related ileitis.
Table 2 Density ( $\%)$ of $\operatorname{Ig} A, \operatorname{Ig} G$, and $\operatorname{Ig} M$ containing cells per millimetre mucosal length in terminal ileum and colonic biopsies

\begin{tabular}{|c|c|c|c|c|}
\hline Group & Number* $(\%)$ & $\% \operatorname{Ig} A$ & $\% \operatorname{Ig} G$ & $\% \operatorname{Ig} M$ \\
\hline \multicolumn{5}{|l|}{ Terminal ileum } \\
\hline Controls & $154(100)$ & $59 \cdot 1$ & $27 \cdot 3$ & $13 \cdot 6$ \\
\hline Crohn's discase & $446(289 \cdot 7)$ & $51 \cdot 1$ & $33 \cdot 2$ & $15 \cdot 7$ \\
\hline Acute inflammation & $261(169 \cdot 5)$ & 64 & $26 \cdot 4$ & $9 \cdot 6$ \\
\hline Chronic inflammation & $455(295 \cdot 4)$ & $46 \cdot 8$ & $33 \cdot 4$ & $19 \cdot 8$ \\
\hline \multicolumn{5}{|l|}{ Colon } \\
\hline Controls & $156(100)$ & $63 \cdot 5$ & $27 \cdot 6$ & 9 \\
\hline Infectious colitis & $299(191 \cdot 7)$ & $74 \cdot 6$ & 17 & $8 \cdot 4$ \\
\hline Ulcerative colitis & $589(377 \cdot 6)$ & $48 \cdot 7$ & $38 \cdot 5$ & $12 \cdot 7$ \\
\hline Crohn colitis & $374(239 \cdot 7)$ & $49 \cdot 2$ & $32 \cdot 3$ & $18 \cdot 5$ \\
\hline Acute inflammation & $284(182)$ & 68 & $22 \cdot 9$ & $9 \cdot 1$ \\
\hline Chronic inflammation & $4(19)(262 \cdot 2)$ & 53 & $25 \cdot 7$ & $21 \cdot 3$ \\
\hline
\end{tabular}

*Total number of Ig containing cells per millimetre mucosa ( $\%$ ).

In the chronic type of arthritis related gut inflammation, again the IgA containing cells were the most important class and their number was significantly different from the control group $(p<0 \cdot 001)$. There was no significant difference with the amount of $\operatorname{IgA}$ containing cells in the acute type of arthritis related gut inflammation or Crohn's disease. The amount of IgG and IgM containing cells was augmented as well (Fig. 3c). It was significantly different from controls and acute arthritis related gut inflammation $(p<0 \cdot 001)$. There was, however, no difference with the Ig distribution pattern found in Crohn's disease.

In Crohn's disease too the $\operatorname{Ig} \mathrm{A}$ containing cells were most numerous. Compared with the control group, the increase of IgA containing cells was highly significant $(p<0 \cdot(001)$. The number of IgG and IgM containing cells was significantly increased as well $(\mathrm{p}<0.001)$ (Fig. 4e)

When the density of the inflammatory infiltrate was considered, there was an increase of Ig containing cells in all studied groups compared with controls. The proportion of IgA containing cells was increased in the acute type of gut inflammation whereas the proportion of IgM containing cells was decreased. In the chronic type of gut inflammation and Crohn's disease, the proportions of IgG and IgM containing cells were increased and the $\operatorname{IgA}$ containing cells were decreased.

\section{COL.ON}

In controls, the IgA containing cells were the most important cell class, IgG and IgM containing cells being far less numerous. In the acute type of arthritis related gut inflammation, the $\operatorname{IgA}$ containing cells were most numerous (Fig. 5a). They were significantly different from controls $(p<0 \cdot 001)$, chronic arthritis related gut inflammation $(p<0 \cdot 05)$, ulcera- 

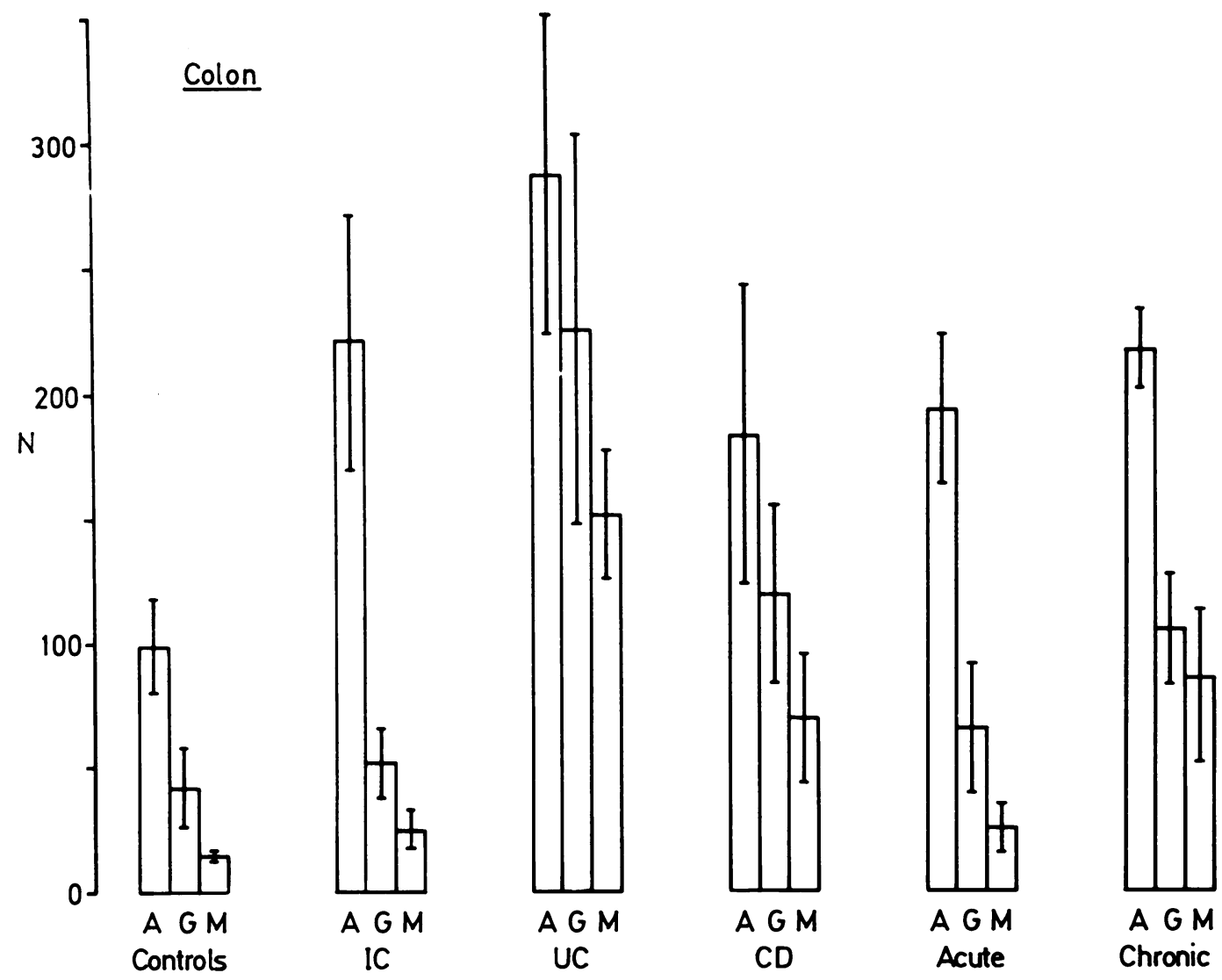

Fig. 3 Number of immunoglobulin containing cells per millimetre colonic mucosa (SD) in 10 controls, 10 patients with infectious colitis, 20 patients with ulcerative colitis, 20 patients with Crohn's colitis, 20 patients with acute and 20 patients with chronic arthritis related colitis.

tive colitis $(\mathrm{p}<0 \cdot 001)$ but not from infectious colitis (Fig. 5b) nor Crohn's disease. The IgG containing cells too were significantly increased, compared to controls $(p<0.005)($ Fig. $5 c, d)$, and different from chronic arthritis related gut inflammation $(p<0 \cdot 001)$, Crohn's disease $(p<0 \cdot 001)$ and ulcerative colitis $(p<0.001)$. There was no difference with the number of IgG containing cells found in infectious colitis. As to the IgM containing cells, their number was significantly increased. It was different from that in chronic arthritis related gut inflammation $(\mathrm{p}<0.001)$, Crohn's disease $(p<0.001)$ and ulcerative colitis $(p<0.001)$, but not from infectious colitis.

In the chronic type of arthritis related gut inflammation again, the IgA containing cells were predominant. Their number was significantly increased $(p<0 \cdot 001)$. Also in comparison with ulcerative colitis there was a significant difference $(p<0 \cdot 001)$. There was no significant difference, however, with infect- ious colitis and Crohn's disease. When compared with controls, the number of IgG containing cells was significantly increased $(p<0 \cdot 001)$. It was different from infectious colitis $(p<0.001)$ as well as from ulcerative colitis $(p<0.001)$ but not from Crohn's disease. The number of IgM containing cells too was significantly increased compared with controls $(p<0 \cdot 001)$, infectious colitis $(p<0 \cdot 001)$, and ulcerative colitis $(p<0 \cdot 001)$. It was not different from Crohn's disease.

In infectious colitis, the number of Ig containing cells was increased because of a rise in the number of both $\operatorname{IgA}$ and $\operatorname{IgM}$ containing cells $(p<0 \cdot 001)$, the former being more numerous. There was a difference with ulcerative colitis $(\mathrm{p}<0 \cdot 02)$ but not with Crohn's disease.

In ulcerative colitis, although the IgG containing cells were present in a high proportion, the $\operatorname{IgA}$ containing cells remained the largest cell group. 


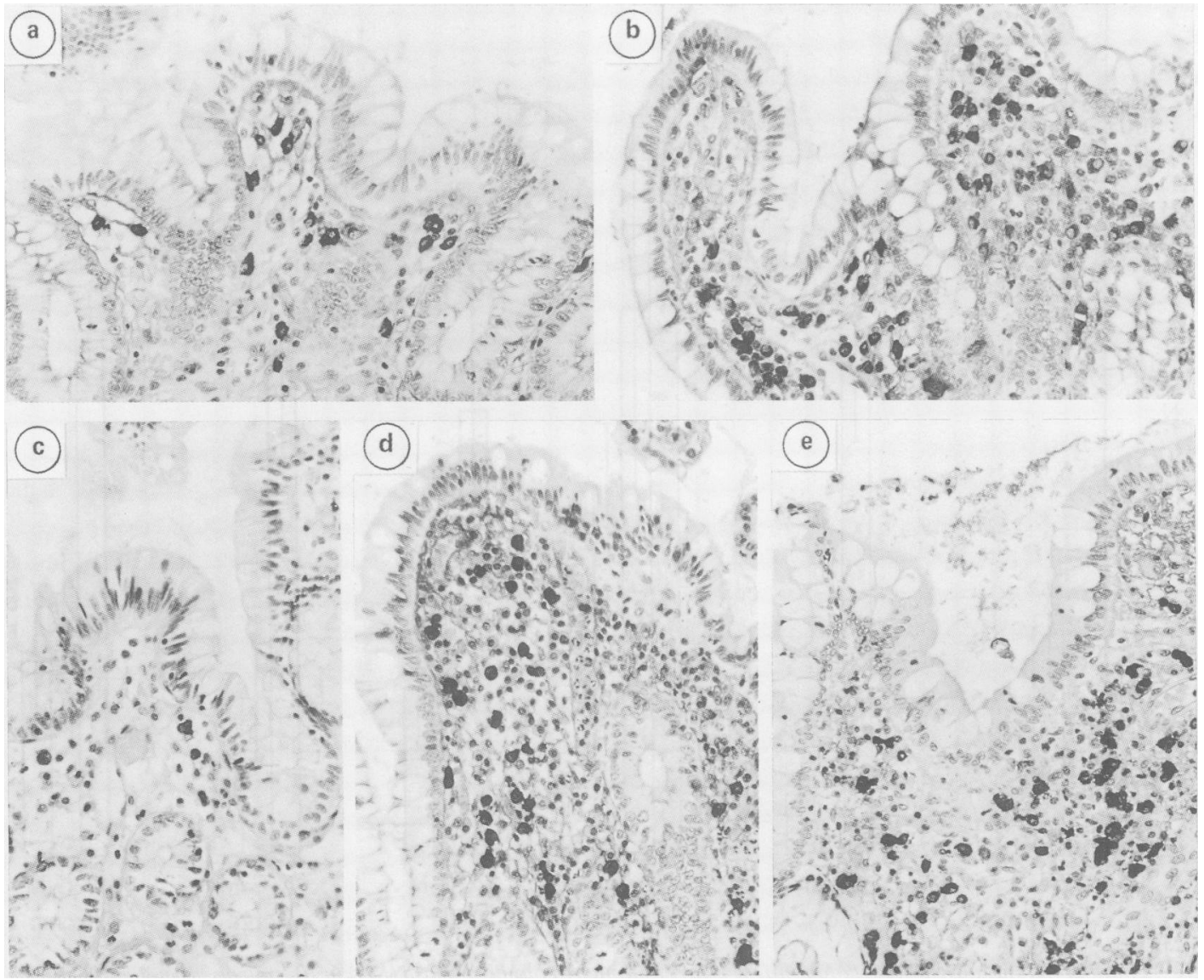

Fig. 4 Immunoperoxidase staining of terminal ileal mucosal biopsies. (a) IgA containing cells in control biopsy; (b) IgA containing cells in acute arthritis related ileitis; (c) lgM containing cells in normal control; (d) IgM containing cells in chronic arthritis related ileitis; (e) $\lg M$ containing cells in (rohn's disease.

The number of $\operatorname{Ig} \mathrm{A}, \operatorname{IgG}$, and $\operatorname{IgM}$ containing cells was significantly different from normal controls $(\mathrm{p}<0 \cdot 001)$. In comparison with Crohn's disease, there was a difference in $\operatorname{IgA}$ and IgG containing cells $(\mathrm{p}<0.001)$ but not in IgM containing cells.

In patients with Crohn's disease, the IgA containing cells were the predominant group. They were significantly different from controls $(p<0 \cdot 001)$. The number of $\operatorname{IgG}$ and $\operatorname{IgM}$ containing cells was increased as well $(\mathrm{p}<0 \cdot(0) 1)$.

In the colon, the proportion of IgA containing cells was increased in acute arthritis related gut inflammation and in infectious colitis and the density of IgG containing cells was decreased. The density of IgM containing cells was increased in chronic arthritis related gut inflammation and in Crohn's disease but only slightly in ulcerative colitis.

\section{Discussion}

With a peroxidase antiperoxidase technique we demonstrated in this study a different pattern of Ig containing cells in acute and chronic gut inflammation in terminal ileal and colonic biopsies of patients, mainly without gastrointestal symptoms, with reactive arthritis or peripheral joint involvement of ankylosing spondylitis, giving immunohistochemical evidence of the existence of two different types of inflammation. The pattern of ileal and colonic Ig containing cells in acute arthritis related gut inflammation is comparable with that found in acute infectious colitis. There was a rise in $\operatorname{IgA}$ and $\operatorname{IgG}$ in terminal ileum and of $\operatorname{Ig} A, \operatorname{IgG}$, and $\operatorname{Ig} M$ classes in colonic biopsies. When compared with Crohn's disease, the number of $\operatorname{IgA}, \operatorname{IgG}$, and $\operatorname{IgM}$ containing 

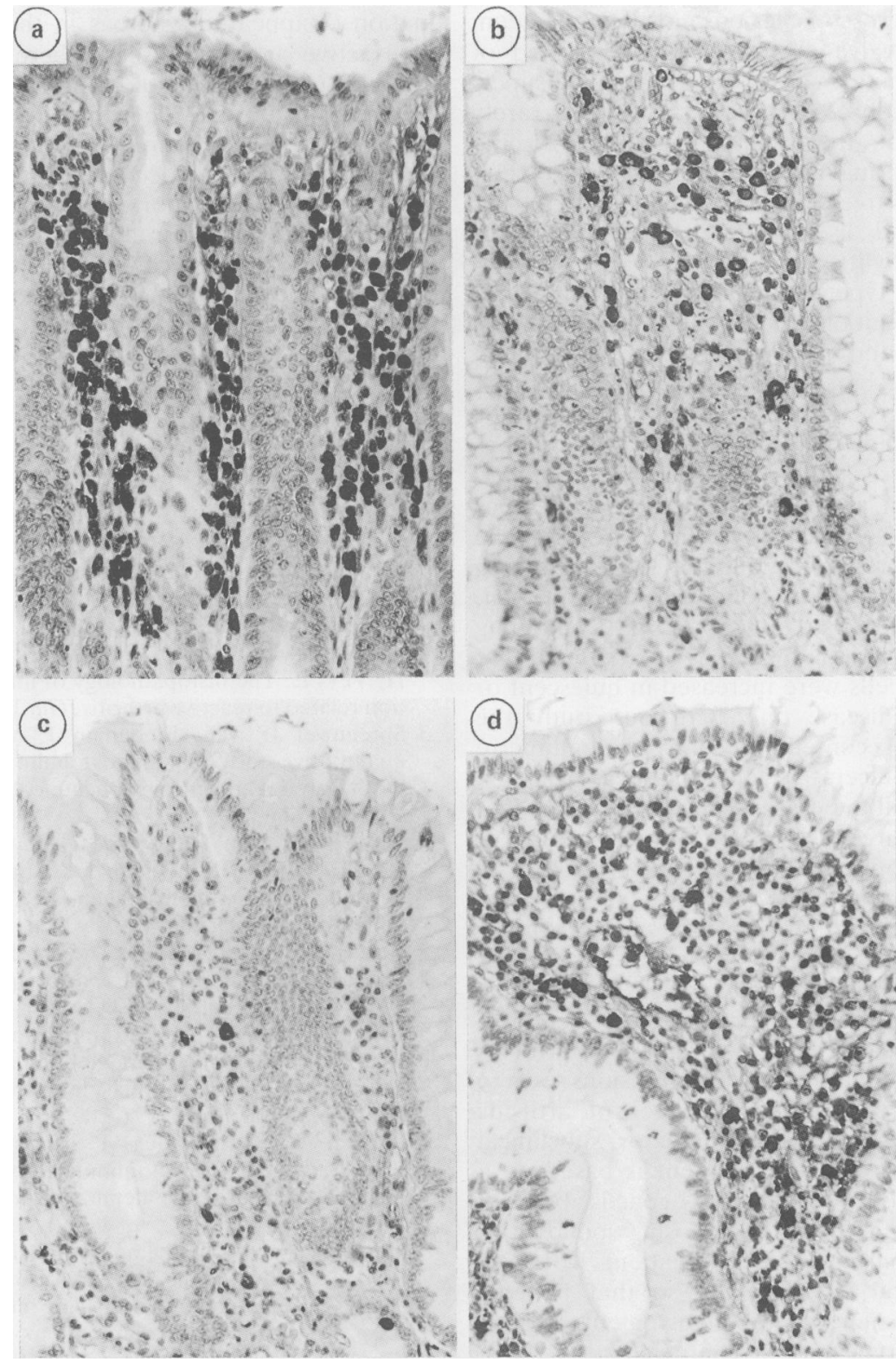

Fig. 5 Immunoperoxidase staining of colonic mucosal biopsies. (a) IgA containing cells in infectious colitis; (b) IgA containing cells in acute arthritis related colitis; (c) IgG containing cells in controls; (d) IgG containing cells in chronic arthritis related colitis.

cells was significantly different in the ileum, whereas in the colon, there was no difference for $\operatorname{IgA}$ but a highly significant difference for IgG and IgM classes. This pattern of the Ig distribution in acute inflammation is similar to what we found in colonic biopsies of patients with acute infectious colitis thus confirming previous observations by other authors." "This may suggest an enterobacterial origin of the arthritis in this group of patients in spite of hitherto negative bacteriological and serological investigations. This is in accordance with the endoscopic finding, however. that $33 \%$ of patients with arthritis related gut inflam- 
mation have macroscopic lesions mostly in the ileum and ileocaecal valve.22 Most lesions consisted of erythematous granular areas or erosions and superficial ulcers. A cobblestone pattern was only rarely seen. In addition this finding could fit with the experience of Ebringer $\mathrm{et} \mathrm{al}^{23}$ that there is a correlation between positive Klebsiella pneumoniae cultures in the faeces and disease activity in patients with ankylosing spondylitis.

In the chronic type of arthritis related gut inflammation, the amount of Ig containing cells is comparable with that found in Crohn's disease. In terminal ileal and colonic biopsies the $\operatorname{IgA}, \operatorname{IgG}$, and $\operatorname{IgM}$ containing groups are raised. This Ig pattern is identical to that of Crohn's disease. Our findings in Crohn's disease and in chronic arthritis related gut inflammation are in agreement with previous observations in chronic idiopathic IBD. ${ }^{561011}$ The finding of an increased amount of IgM containing cells in ulcerative colitis is somewhat controversial. Some authors noticed an increase of IgM containing cells in ulcerative colitis ${ }^{56}$ whereas others found that IgM containing cells were increased in quiescent or active Crohn's disease only." In our study the increase of $\operatorname{IgM}$ containing cells per millimetre mucosa length in ulcerative colitis might be explained by the fact that all the cases of ulcerative colitis that we studied featured active disease with a loss of crypts, crypt atrophy, and a subsequent increase of the lamina propria area. When the cell density was considered, however, there was only a minor increase in IgM containing cells which was far less pronounced than in Crohn's disease or chronic arthritis related gut inflammation.

The immunohistochemical findings in arthritis related gut inflammation with chronic lesions seem to indicate that a considerable number of arthritis patients suffer from asymptomatic or subclinical Crohn's disease. Another argument is based on a clinical observation. The HLA-B27 gene is absent in only $4-5 \%$ of patients with ankylosing spondylitis ${ }^{24}$ and it is present only in $20-50 \%$ of patients with IBD and axial skeletal involvement ${ }^{25}$ so that patients with IBD and axial skeletal involvement without HLA-B27 phenotype may have more chance to have pre or subclinical Crohn's disease. Moreover, the histopathological lesions found in this group of patients are very similar to (early) Crohn's disease. 22260

There is, however, a need for longer follow up in order to resolve this relationship definitely. The performance of a repeat ileocolonoscopy four to 22 months after the first one in 14 patients seemed to be of help in the statement of disease activity. ${ }^{27}$ In six of seven patients with clinical remission of the articular symptoms, the histological signs of intestinal inflam- mation disappeared whereas in the seven patients with active articular disease there was still histological evidence of ileocolonic inflammation.

In conclusion, the determination of mucosal $\mathrm{Ig}$ containing cells has been of help in order to unravel the histopathological spectrum of arthritis related gut inflammation, giving more objective evidence for the existence of two different inflammatory patterns, with a distinct clinical course. ${ }^{27}$ The disappearance of the acute type of gut inflammation is followed by clinical articular remission whereas patients with chronic active intestinal inflammation have a persistence of the articular symptoms.

\section{References}

1 Mielants H, Veys E, Cuvelier C, De Vos $M$, Botelberghe L. HLA-B27 related arthritis and bowel inflammation. Part 2. Ileocolonoscopy and bowel histology in patients with HLA-B27 related arthritis. J Rheumatol 1985; 12: 293-8.

2 Cuvelier C, Barbatis C, Mielants H, De Vos M, Roels $\mathrm{H}$, Veys $\mathrm{E}$. The histopathology of intestinal inflammation related to reactive arthritis. Gut 1987; 28: 394-401.

3 Spreeuwel JP van, Lindeman J, Meijer CJLM. A quantitative study of immunoglobulin containing cells in the differential diagnosis of acute colitis. J Clin Pathol 1985; 38: 774-7.

4 Spreeuwel JP van, Duursma GC, Meijer CJLM, Bax R, Rosekrans PCM, Lindeman J. Campylobacter colitis. Histological, immunohistochemical and ultrastructural findings. Gut 1985; 26: 945-51.

5 Skinner JM, Whitehead R. The plasma cells in inflammatory bowel disease of the colon: a quantitative study. J Clin Pathol 1974; 27 : 643-6.

6 Baklien K, Brandtzaeg P. Comparative mapping of the local distribution of immunoglobulin containing cells in ulcerative colitis and Crohn's disease of the colon. Clin Exp Immunol 1975; 22: 197-209.

7 Baklien K, Brandtzaeg P. Immunohistochemical characterization of local immunoglobulin formation in Crohn's disease of the ileum. Scand J Gastroenterol 1976; 11 : 447-57.

8 Meuwissen SGM, Feltkamp-Vroom ThM, Brutel de la Rivière A, von dem Borne AEGKr, Tytgat GN. Analysis of the lymphoplasmacytic infiltrate in Crohn`s disease with special reference to identification of lymphocyte subpopulations. Gut 1976; 17: 770-80.

9 Otto HF, Gebbers JO. Immunhistologische Untersuchungen zur lokalen humoralen Immunreaktion bei unbehandelter Colitis ulcerosa. Inn Med 1978; 2: 69-77.

10 Rosekrans PCM, Meijer CJLM, Wal AM Van Der, Cornelisse CJ, Lindeman J. Immunoglobulin containing cells in inflammatory bowel disease of the colon: a morphometric and immunohistochemical study. Gut 1980; $21: 941-7$.

11 Scott BB, Goodall A, Stephenson P, Jenkins O, Rectal mucosal plasma cells in inflammatory bowel disease. Gut 1983; 24: 519-24.

12 Meijer CJLM, Bosman FT, Lindeman J. Evidence for 
predominant involvement of the B-cell system in the inflammatory process in Crohn's disease. Scand $J$ Gastroenterol 1979; 14: 21-32.

13 Stodell MA, Butler RC, Zemelman VA, Henry K, Brewerton DA. Increased numbers of IgG containing cells in rectal lamina propria of patients with ankylosing spondylitis. Ann Rheum Dis 1984; 43: 172-7.

14 Calin A. The spondyloarthropathies. Orlando, Florida: Osborne \& Stratton Inc, 1984

15 Morson BC. In Sommers SC, ed. Pathology annual. New York: Appleton-Century-Crofts, 1974: 209-30.

16 Rotterdam H, Sommers SC. Biopsy diagnosis of the digestive tract. New York: Raven Press, 1981: 265-72.

17 Whitehead R. Mucosal biopsy of the gastrointestinal tract. London: WB Saunders, 1985: 227-38.

18 Mielants H, Veys EM, De Vos M, Cuvelier C. Gut inflammation in the pathogenesis of idiopathic forms of reactive arthritis and in the peripheral joint involvement of ankylosing spondylitis. In: Mielants H, Veys EM, eds. Spondyloarthropathies. Involvement of the gut. Amsterdam: Elsevier Science Publishers, 1987: 11-21.

19 Bosman FT, Lindeman J, Kuiper G, Van der Wal A, Kreunig $J$. The influence of fixation on immunoperoxidase staining of plasma cells in paraffin sections of intestinal biopsy specimens. Histochemistry 1977; 53: $57-62$.
20 Sternberger L. Immunocytochemistry. Englewood Cliffs, NJ: Prentice Hall, 1974: 53.

21 Brandtzaeg $P$, Baklien $K$, Fausa $O$, Hoel PS. Immunohisto-chemical characterization of local immunoglobulin formation in ulcerative colitis. Gastroenterology 1974; 66: 1123-36.

22 De Vos M, Cuvelier C, Mielants H, Veys E, Barbier F. Ileocolonoscopy and Rheumatic disease. Submitted for publication.

23 Ebringer RW, Cawdell DR, Cowling P, et al. Sequential studies in ankylosing spondylitis. Association of Klebsiella pneumoniae with active disease. Ann Rheum Dis 1978; 37: 146.

24 Brewerton DA, Hart FD, Nicholls A, Caffrey M, James DCO, Sturrock RD. Ankylosing spondylitis and HLA W27. Lancet 1973; i: 904-7.

25 Morris RI, Metzger AL, Bluestone R, Terasaki PJ. HLA-B27. A useful discrimination in the arthropathies of inflammatory bowel disease. N Engl J Med 1974; 290: 1117-9.

26 Rickert RR, Carter HW. The 'early' ulcerative lesion of Crohn's disease: correlative light and scanning electronmicroscopic studies. J Clin Gastroenterol 1980; 2: 11-19.

27 Mielants H, Veys EM, Joos R, Cuvelier C, De Vos M. Repeat ileocolonoscopy in reactive arthritis. $J$ Rheumatol 1987; 14: 456-8. 